\section{ACKOWLEDLEGEMENTS}

We thank to Minister of Research and Technology of Republic of Indonesia to support funding for this research. To Mr. Anda Suhanda thank you for helping in the field.

\section{REFERENCES}

Bhagat RM, SI Bhuiyan and K Moody. 1996. Water, tillage and weed interactions in lowland tropical rice: a review. Agric Water Manage 31: 165-184.

Bouman BAM and TP Tuong. 2001. Field water management to save water and increase its productivity in irrigated lowland rice. Agric Water Manage 49: 11-30.

Cho JY, KW Han and JK Choi. 2000. Balance of nitrogen and phosphorus in a paddy field of central Korea. Soil Sci Plant Nutr 46: 343-354.

Cho JY, KW Han, JK Choi, YJ Kim and KS Yoon. 2002. N and P losses from paddy field plot in Central Korea. Soil Sci Plant Nutr 48: 301-306.

Dobermann A, PCS Cruz and KG Cassman. 1996. Fertilizer inputs, nutrients balance, and soil nutrient-supplying power in intensive, irrigated rice systems, I. Potassium uptake and K balance. Nutr Cycling Agroecosyst 46 (1): 1-10. doi: 10.1007/BF00210219.

Fageri NK and CV Balligar. 2001. Improving nutrient use efficiency of annual crops in Brazilian acid soils for sustainable crop production. Commun Soil Sci Plan Anal 32 (7 and 8): 1301-1319.

Fenning JO, T Adjie, E Gyapong, Yeboah, EO Ampontuah and G Wuansah. 2005. Soil Fertility status and potential organic inputs for improving smallholder crop production in the interior savannah zone of Ghana. J Sustain Agric 25 (4): 69-92.

Kaleeswari RK and S Subramanian. 2004. Impact of organic manure and inorganic phosphatic fertiliser on yield and nutrient uptake in a rice-rice cropping system. IRRN29 (2): 57-60.

Kemmler G. 1971. Response of high yielding paddy varieties to potassium: Experimental results from various rice growing countries. In: JS Kanwar, NPDatta, SS Bains, DR Bhumbla and TD Biswas (eds), Proceedings of international symposium on soil fertility evaluation 1. New Delhi, pp. 391-406.

Min YK, CS Myung and KK Min. 2007. Linking hydrometeorological factors to the assessment of nutrient loading to stream from large plotted paddy rice fields. Agric Water Manage 87: 223-228.

Sanchez PA and MV deCalderon. 1971. Timing of nitrogen application for rice grown under intermittent flooding in the coast of Peru. In: JS Kanwar, NP Datta, SS Bains, DR Bhumbla and TD Biswas (eds). Proceedings of International Symposium on Soil Fertility Evaluation 1. New Delhi, pp. 595-602.

Singh B, RK Niranjan and RK Pathak. 2001. Effect of organic matter resources and inorganic fertilisers on yield and nutrient uptake in the rice-wheat cropping system. IRRN 26 (2): 57-58.
Soepartini M. 1995. Status kalium tanah sawah dan tanggap padi terhadap pemupukan $\mathrm{KCl}$ di Jawa Barat. Pemberitaan Pen Tanah 13: 27-40 (in Indonesian).

Soil Research Institute. 2009. Analisis kimia tanah, tanaman, air dan pupuk (Procedure to measure soil, plant, water and fertilisers). Soil Research Institute, Bogor. 234 p. (in Indonesian).

Sudjadi M. 1984. Masalah kesuburan tanah Podsolik Merah Kuning dan Kemungkinan pemecahannya. In: Prosiding Penelitian Pola Usahatani Menunjang Transmigrasi. badan Litbang Pertanian, Jakarta, pp. 3-10 (in Indonesian).

Sukristiyonubowo and E Tuherkih. 2009. Rice production in terraced paddy field systems. J Penel Perta Tan Pangan 28 (3): 139-147.

Sukristiyonubowo and GD Laing. 2010. Seasonal variation of yields and nutrients uptakes of IR 64 grown in terraced paddy field system. J Trop Soils 16(3): 201-210

Sukristiyonubowo, IA Sipahutar, T Vadari and A Sofyan. 2011. Management of Inherent soil fertility of newly opened wetland rice field for sustainable rice farming in Indonesia. J Plant Breed Crop Sci 3 (8): 146-153.

Sukristiyonubowo, Mulyadi, P Wigena and A Kasno. 1993. Effect of organic matter, lime and NPK fertilizer added on soil properties and yield og peanut. $J$ Indon Soil Fert 11: 1-7.

Sukristiyonubowo, S Ritung and K Nugroho. 2012. Nitrogen and potassium balances of newly opened wetland rice field. J Agric Sci Soil Sci 2 (5): 207-216.

Sukristiyonubowo. 2007. Nutrient balances in terraced paddy fields under traditional irrigation in Indonesia. $[\mathrm{PhD}$ thesis]. Faculty of Bioscience Engineering, Ghent University, Ghent, Belgium. 184 p.

Uexkull HRV. 1989. Nutrient Cycling. In: E Pushparajah (ed). Soil Management and Smallholder Development in the Pacific Islands. Proceedings of the workshop organized by The International Board for Soil Research and Management, Bangkok Thailand, pp. 121-132.

Whitbread AM, GJ Blair and RDB Lefroy. 2000. Managing legume leys, residues and fertilisers to enhance the sustainability of wheat cropping system in Australia. 1. The effects on wheat yields and nutrient balance. Soil Till Res 54: 63-75.

Yan D, D Wang and L Yang. 2007. Long term effect chemical fertiliser, straw and manure on labile organic matter in a paddy soil. Biol Fertil Soil 44: 93-101.

Yang C, L Yang, Y Yang and O Zhu. 2004. Rice root growth and nutrient uptake as influenced by organic manure in continuously and alternately flooded paddy soils. Agric Water Manage 70: 67-81.

Zhang QC and GH Wang. 2005. Studies on nutrient uptake of rice and characteristics of soil microorganisms in a long term fertilization experiment for irrigated rice. J Zhejiang Univ Sci 6 (2): 147-154. 
Table 4. Nutrient taken up by rice grain and rice straw of Ciliwung variety planted in newly opened wetland rice in Panca Agung site, Bulungan District.

\begin{tabular}{|c|c|c|c|c|c|c|}
\hline \multirow{2}{*}{ Treatments } & \multicolumn{2}{|c|}{$\mathrm{N}$ uptake } & \multicolumn{2}{|c|}{ P uptake } & \multicolumn{2}{|c|}{ K uptake } \\
\hline & Rice Grain & Rice Straw & Rice Grain & Rice Straw & Rice Grain & Rice Straw \\
\hline & $\ldots \ldots \ldots \ldots . .$. & …….......... & $\mathrm{kg} \mathrm{ha}^{-1}$ seasc & ㄱ... & ............. & \\
\hline T0 & 28.11 & 33.70 & 2.01 & 2.30 & 5.77 & 90.00 \\
\hline $\mathrm{T} 1$ & 35.34 & 24.82 & 2.67 & 2.76 & 7.72 & 117.81 \\
\hline $\mathrm{T} 2$ & 35.84 & 43.67 & 2.79 & 4.02 & 6.49 & 149.60 \\
\hline $\mathrm{T} 3$ & 44.53 & 40.37 & 4.42 & 3.25 & 9.94 & 142.62 \\
\hline $\mathrm{T} 4$ & 54.91 & 46.80 & 9.01 & 4.68 & 9.44 & 161.72 \\
\hline $\mathrm{T} 5$ & 46.36 & 37.73 & 6.46 & 6.29 & 8.36 & 148.29 \\
\hline
\end{tabular}

In line with the nutrients concentrations, the $\mathrm{N}$, $\mathrm{P}$, and $\mathrm{K}$ uptakes were also different among the treatments (Table 4). This was due to a significant increase of rice plant weights during rice growth and their concentrations. These results confirm to the findings reported by Sukristiyonubowo (2007) that $\mathrm{N}, \mathrm{P}$ and $\mathrm{K}$ uptakes increased in relation to the rice growth and the highest $\mathrm{N}, \mathrm{P}$ and $\mathrm{K}$ uptakes were taken place at harvest stage. Compared to T0 (farmers practices), T1 (farmer practices + straw compost + dolomite) to T5 (NPK with recommendation rate in which $\mathrm{N}$ and $\mathrm{K}$ were split two times + straw compost + dolomite) treatments showed higher $\mathrm{N}, \mathrm{P}$ and $\mathrm{K}$ uptakes, indicating sufficient nutrients were needed during rice growth and development. The results also confirmed that the highest $\mathrm{N}, \mathrm{P}$ and $\mathrm{K}$ uptakes were observed in T4 (NPK with recommendation rate + Compost + Dolomite, in which $\mathrm{N}$ and $\mathrm{K}$ were split three time $50 \%$ at planting time, $25 \%$ at 21 DAT and the rest given at 35 DAT). The highest nutrient uptakes were about $59.91 \mathrm{~kg} \mathrm{~N}, 9.01 \mathrm{~kg} \mathrm{P}$, and $9.44 \mathrm{~kg} \mathrm{~K} \mathrm{ha}^{-1}$ season $^{-1}$ and $46.80 \mathrm{~kg} \mathrm{~N}, 4.68 \mathrm{~kg} \mathrm{P}$, and $161.72 \mathrm{~kg}$ $\mathrm{K} \mathrm{ha}^{-1}$ season $^{-1}$ for rice grains and rice straw, respectively.

As in fact only rice residues were left in the field, the nutrient amounts taken up by rice straw and rice grains reflected the nutrients removal from the field through harvest product. The total removal ranged between 61.81 and $101.71 \mathrm{~kg} \mathrm{~N}, 4.31$ and $13.69 \mathrm{~kg} \mathrm{P}, 95.77$ and $171.16 \mathrm{~kg} \mathrm{~K} \mathrm{ha}^{-1}$ season $^{-1}$ depending on the treatments and indeed the $\mathrm{T} 4$ treatment showed the highest nutrient removal by harvest product. Similar ranges have been reported in other studies. Uexkull (1970) found that about $77 \mathrm{~kg} \mathrm{~N}, 14 \mathrm{~kg} \mathrm{P}$, and $151 \mathrm{~kg} \mathrm{~K} \mathrm{ha}^{-1}$ season $^{-1}$ were removed through rice straw and rice grains during a wet season by a high yielding variety. These amounts were higher than those removed by an improved local variety. Sanchez and de Calderon (1971) also noticed that the $\mathrm{N}$ uptake at harvest ranged from 34 to $107 \mathrm{~kg} \mathrm{~N} \mathrm{ha}^{-1}$ season $^{-1}$, depending on rice variety. Kemmler (1971) observed that with a yield of $5 \mathrm{Mg} \mathrm{ha}^{-1}$ season $^{-1}$, between 90 and 100 $\mathrm{kg} \mathrm{N}, 20$ and $30 \mathrm{~kg} \mathrm{P,} 60$ and $80 \mathrm{~kg} \mathrm{~K}$ are removed from the field by high yielding varieties. Sukristiyonubowo (2007) concluded that total nutrient removal through rice grains and rice straw of IR 64 variety varied from 88 to $164 \mathrm{~kg} \mathrm{~N}, 8$ to 16 $\mathrm{kg} \mathrm{P}$, and 104 to $198 \mathrm{~kg} \mathrm{~K} \mathrm{ha}^{-1}$ season $^{-1}$ in the wet season year 2003-2004 and from 94 to $165 \mathrm{~kg} \mathrm{~N}$, 10 to $18 \mathrm{~kg} \mathrm{P}$, and 107 to $179 \mathrm{~kg} \mathrm{~K} \mathrm{ha}^{-1}$ season $^{-1}$ in the dry season year 2004 .

The nutrients removed through harvest product also meant that about 137 to $226 \mathrm{~kg}$ urea, 22 to 68 $\mathrm{kg}$ TSP and 190 to $339 \mathrm{~kg} \mathrm{KCl} \mathrm{ha}^{-1}$ season $^{-1}$ were taken out from the field via rice grain and rice straw. Therefore, to avoid nutrient mining and to maintain its inherent soil fertility about 137 to $226 \mathrm{~kg}$ urea, 22 to $68 \mathrm{~kg}$ TSP and 190 to $339 \mathrm{~kg} \mathrm{KCl} \mathrm{ha}{ }^{-1}$ season $^{-1}$ should be added. Like in T4, the urea and $\mathrm{KCl}$ should be split three time $50 \%$ at planting time, $25 \%$ at 21 DAP and the last at 35 DAP. As recently the spirit of Indonesian agriculture practices is applying more organic farming, the application of $250 \mathrm{~kg}$ urea, $100 \mathrm{~kg} \mathrm{SP}-36$ and 100 $\mathrm{kg} \mathrm{KCl} \mathrm{ha}^{-1}$ season $^{-1}$ plus $2.000 \mathrm{~kg}$ compost made rice from straw and $2.000 \mathrm{~kg}$ dolomite $\mathrm{ha}^{-1}$ season $^{-1}$ can also be concerned.

\section{CONCLUSIONS}

Depending on the inputs, total nutrients removal through rice grains and rice straw varied from 61.81 and $101.71 \mathrm{~kg} \mathrm{~N}, 4.31$ and $13.69 \mathrm{~kg} \mathrm{P}, 95.77$ and $171.16 \mathrm{~kg} \mathrm{~K} \mathrm{ha}^{-1}$ season $^{-1}$. These were equal to 137 to $225 \mathrm{~kg}$ urea, 50 to $160 \mathrm{~kg} \mathrm{SP}-36$ and 190 to 339 $\mathrm{kg} \mathrm{ha}^{-1}$ season $^{-1}$. Therefore, to replace the nutrients taking away by harvest product and to manage its soil fertility those amount of mineral fertilisers should be added, besides to keep the quantity and quality of rice yields. 
Table 2.Rice biomass production of Ciliwung variety at different treatments and their enhancement compared to farmer practices cultivated in newly opened wetland rice at Panca Agung site, Bulungan District.

\begin{tabular}{clllcc}
\hline \multirow{2}{*}{ Treatment } & \multicolumn{3}{c}{ Biomass Production $\left(\mathrm{Mg} \mathrm{ha}^{-1}\right)$} & \multicolumn{2}{c}{ Increasing rice grain yield } \\
\cline { 2 - 6 } & Rice Residue & Rice Straw & Rice Grain & $\mathrm{Mg} \mathrm{ha}^{-1}$ & $\%$ \\
\hline T0 & $2.76 \pm 0.4 \mathrm{c}$ & $3.83 \pm 0.4 \mathrm{~b}$ & $2.51 \pm 0.6 \mathrm{~d}$ & - & 18 \\
T1 & $3.05 \pm 0.4 \mathrm{bc}$ & $3.94 \pm 0.7 \mathrm{~b}$ & $2.97 \pm 0.03 \mathrm{~cd}$ & 0.46 & 23 \\
T2 & $3.61 \pm 0.2 \mathrm{ab}$ & $5.02 \pm 0.5 \mathrm{a}$ & $3.09 \pm 0.3 \mathrm{bc}$ & 0.58 & 47 \\
T3 & $3.90 \pm 0.2 \mathrm{a}$ & $4.64 \pm 0.6 \mathrm{ab}$ & $3.68 \pm 0.4 \mathrm{abc}$ & 1.17 & 71 \\
T4 & $4.01 \pm 0.1 \mathrm{a}$ & $5.20 \pm 0.4 \mathrm{a}$ & $4.29 \pm 0.4 \mathrm{a}$ & 1.78 & 51 \\
T5 & $4.18 \pm 0.3 \mathrm{a}$ & $5.24 \pm 0.2 \mathrm{a}$ & $3.80 \pm 0.3 \mathrm{ab}$ & 1.29 & \\
\hline CV $(\%)$ & 16.55 & 15.47 & 20.41 & & \\
\hline
\end{tabular}

Note: The mean values in the same column followed by the same letter are not statistically different by DMRT test. T0: Farmer Practices (as control); T1: Farmer Practices + Compost + Dolomite; T2: NPK with recommendation rate; T3: NPK with recommendation rate (N and $\mathrm{K}$ were split $3 \times)$; T4: NPK with recommendation rate + Compost + Dolomite ( $\mathrm{N}$ and $\mathrm{K}$ were split $3 \times)$; T5: NPK with recommendation rate + Compost + Dolomite.

T4 (NPK with recommendation rate + Compost + Dolomite, in which $\mathrm{N}$ and $\mathrm{K}$ were split three time $50 \%$ at planting time, $25 \%$ at $21 \mathrm{DAT}$ and the rest was given at 35 DAT) showed the highest rice residues, rice straw, and rice productions, and significantly different with others treatments. The yields reached were about $4.01 \pm 0.1 ; 5.20 \pm 0.4$ and $4.29 \pm 0.4 \mathrm{Mg} \mathrm{ha}^{-1}$ for rice residues, rice straw, and rice grain, respectively. Compared to T0 (farmers practices), the improvement was about $1.78 \mathrm{Mg} \mathrm{ha}^{-1}$ or $71 \%, 1.37$ or $26 \% 1.25$ or $45 \%$ for rice grain, rice straw and rice residues, respectively. The farmers mentioned until one year after conversion to wetland rice areas, the rice yield was considered high, reaching $2.0-2.5 \mathrm{Mg} \mathrm{ha}^{-1}$, afterward reduced to 1.0 - $1.5 \mathrm{Mg} \mathrm{ha}^{-1}$. Therefore, these findings mean that application of NPK with recommended rate plus 2 $\mathrm{Mg}$ dolomite $\mathrm{ha}^{-1}$ and $2 \mathrm{Mg}$ compost ha ${ }^{-1}$ are essential to enhance and sustain rice yield of newly opened wetland rice. These make improving of soil fertility resulting in more nutrients available for rice growth (Sukristiyonubowo et al. 2011).

\section{Nutrient Concentrations and Nutrient Removal in Rice Harvest Products}

The results indicated that the concentrations of $\mathrm{N}, \mathrm{P}$, and $\mathrm{K}$ in rice grain and rice straw in all treatments increased compared to farmers practices (Table 3). The highest concentrations of N, P, and $\mathrm{K}$ in rice grain and rice straw were observed at $\mathrm{T} 4$ (NPK with recommendation rate + Compost + Dolomite, in which $\mathrm{N}$ and $\mathrm{K}$ were split three time $50 \%$ at planting time, $25 \%$ at 21DAT and the rest given at 35 DAT), indicating more nutrient quantity was taken up by rice grain and rice straw. In addition, these also mean more nutrients were removed by rice grain and rice straw. The concentrations of $\mathrm{N}$, $\mathrm{P}$, and $\mathrm{K}$ in rice grain were $1.28 \% \mathrm{~N}, 0.21 \% \mathrm{P}$, and $0.27 \% \mathrm{~K}$ and in rice straw were $0.90 \% \mathrm{~N}, 0.12 \%$ $\mathrm{P}$, and $3.11 \% \mathrm{~K}$.

The data also suggested that the concentrations of $\mathrm{N}$ and $\mathrm{P}$ in rice grain were higher than in the rice straw. This presumably because of higher protein contents in rice grain than in rice straw.

Table 3. Nutrient concentrations of rice grain and rice straw of Ciliwung variety planted in newly opened wetland rice in Panca Agung site, Bulungan District.

\begin{tabular}{|c|c|c|c|c|c|c|}
\hline \multirow{2}{*}{ Treatments } & \multicolumn{2}{|c|}{$\mathrm{N}$ concentration } & \multicolumn{2}{|c|}{$\mathrm{P}$ concentration } & \multicolumn{2}{|c|}{$\mathrm{K}$ concentration } \\
\hline & Rice Grain & Rice Straw & Rice Grain & Rice Straw & Rice Grain & Rice Straw \\
\hline & ․ & … & .................. & ㄱ..ㄱ..……...... & ……........ & ……........ \\
\hline T0 & 1.12 & 0.88 & 0.08 & 0.06 & 0.21 & 2.35 \\
\hline $\mathrm{T} 1$ & 1.19 & 0.63 & 0.09 & 0.07 & 0.26 & 2.99 \\
\hline $\mathrm{T} 2$ & 1.16 & 0.87 & 0.09 & 0.08 & 0.23 & 2.98 \\
\hline $\mathrm{T} 3$ & 1.21 & 0.87 & 0.12 & 0.07 & 0.27 & 3.16 \\
\hline $\mathrm{T} 4$ & 1.28 & 0.90 & 0.21 & 0.12 & 0.22 & 3.11 \\
\hline T5 & 1.22 & 0.72 & 0.17 & 0.09 & 0.22 & 2.83 \\
\hline
\end{tabular}


Table 1. The detail treatment of the effect of NPK fertilization, dolomite and rice straw compost in newly opened wetland rice.

\begin{tabular}{clccccc}
\hline Code & \multicolumn{1}{c}{ Treatment } & $\begin{array}{c}\text { Urea } \\
\left(\mathrm{kg} \mathrm{ha}^{-1)}\right.\end{array}$ & $\begin{array}{c}\text { SP-36 } \\
\left(\mathrm{kg} \mathrm{ha}^{-1}\right)\end{array}$ & $\begin{array}{c}\mathrm{KCl} \\
\left(\mathrm{kg} \mathrm{ha}^{-1}\right)\end{array}$ & $\begin{array}{c}\text { Dolomite } \\
\left(\mathrm{kg} \mathrm{ha}^{-1}\right)\end{array}$ & $\begin{array}{c}\text { Compost } \\
\left(\mathrm{kg} \mathrm{ha}^{-1}\right)\end{array}$ \\
\hline T0 & Farmer practices (as control) & 100 & 100 & - & - & - \\
$\mathrm{T} 1$ & $\begin{array}{l}\text { Farmer practices + Compost }+ \\
\text { Dolomite }\end{array}$ & 100 & 100 & - & 2000 & 2000 \\
$\mathrm{~T} 2$ & NPK with recommendation rate & 250 & 100 & 100 & - & - \\
$\mathrm{T} 3$ & $\begin{array}{l}\text { NPK with recommendation rate } \\
\text { (N and K were split 3 times) }\end{array}$ & 250 & 100 & 100 & - & 2000 \\
$\mathrm{~T} 4$ & $\begin{array}{l}\text { NPK with recommendation rate + } \\
\text { Compost + dolomite (N and K were } \\
\text { split 3times) }\end{array}$ & 250 & 100 & 100 & 2000 & 2000 \\
NPK with recommendation rate + & 250 & 100 & 100 & 2000 & 2000 \\
Compost + dolomite & & & & & \\
\hline
\end{tabular}

Note: $\mathrm{T} 3=$ NPK with recomendation rate, in which $\mathrm{N}$ and $\mathrm{K}$ were split three time $50 \%$ at planting time, $25 \%$ at $21 \mathrm{DAT}$ and the rest given at 35 DAT. T4 $=$ NPK with recommendation rate + Compost + Dolomite, in which N and $\mathrm{K}$ were split three time $50 \%$ at planting time, $25 \%$ at $21 \mathrm{DAT}$ and the rest given at $35 \mathrm{DAT}$.

after transplanting (DAT). For the treatment T3 and $\mathrm{T} 4$, urea and $\mathrm{KCl}$ were split three times namely $50 \%$ at planting time, $25 \%$ at 21 DAT and the last $25 \%$ was given at 35 DAT. Dolomite as much as 2 $\mathrm{Mg} \mathrm{ha}^{-1}$ and rice straw compost of about $2 \mathrm{Mg} \mathrm{ha}^{-1}$ were broadcasted a week before planting. The detailed treatment is presented in Table 1.

\section{Plant Preparation}

Ciliwung rice variety was cultivated as plant indicator. Transplanting was conducted at the end of June 2009 and harvest at the beginning of October 2009. Twenty-one-day old seedlings were transplanted at about $25 \mathrm{~cm} \times 25 \mathrm{~cm}$ plant and row spacing with about three seedlings per hill. Rice biomass productions including grains, straw, and residues were observed. On a hectare basis, biomass productions were extrapolated from sampling areas of $1 \mathrm{~m} \times 1 \mathrm{~m}$. These sampling units were randomly selected at every plot. Rice plants were cut about 10 to $15 \mathrm{~cm}$ above the ground surface. The samples were manually separated into rice grains, rice straw, and rice residues. Rice residues included the roots and the part of the stem (stubble) left after cutting. Fresh weights of rice grain, rice straw, and rice residue were immediately weighed at each sampling unit.

\section{Harvesting and Observation}

Plants were sampled at harvest and were collected from every plot, one hill per plot. After pulling out, the plant roots were washed with canal water. For the laboratory analyses, the samples were treated according to procedures of the Analytical
Laboratory of the Soil Research Institute, Bogor. Samples were washed with deionised water to avoid any contamination, and dried at $70^{\circ} \mathrm{C}$. The dried samples were ground and stored in plastic bottles. Nitrogen was determined by wet ashing using concentrated $\mathrm{H}_{2} \mathrm{SO}_{4}(97 \%)$ and selenium, while $\mathrm{P}$ and $\mathrm{K}$ were measured after wet ashing using $\mathrm{HClO}_{4}$ and $\mathrm{HNO}_{3}$ (Soil Research Institute 2009).

Nutrient removal by harvest product was calculated according to sum of nutrient taken away by rice grain and by rice straw. Nutrient removed by rice grain was estimated based on rice grain yield multiplied by nutrient concentration in the grains. Meanwhile, nutrient taken out by rice straw was calculated according to the total rice straw production multiplied by nutrient concentration in the straw. According to Sukristiyonubowo (2007) as the rice residue is remained in the field, therefore it is not considered as nutrient taken out by rice harvest products.

\section{Statistical Analysis}

All data were statistically examined by analysis of variance (ANOVA) and computed using software SPSS program. Means were compared to Duncan Multiple Range Test (DMRT) with a 5\% degree of confidence.

\section{RESULTS AND DISCUSSION}

\section{Rice Production}

All treatments significantly enhanced the rice biomass production, namely rice residues, ricestraw and rice grain (Table 2). In addition, at the treatment 
production, proper management practices using more organic matter plus liming, and inorganic fertilizer are recommended (Fageria and Baligar 2001; Fenning et al. 2005; Yan et al. 2007; Sukristiyonubowo et al. 2012; Sukristiyonubowo et al. 2011; Sukristiyonubowo and Du Laing 2010; Sukristiyonubowo and Tuherkih 2009; Sukristiyonubowo et al. 1993; Whitbread et al. 2003). The effects of fertilisers on crop production in terms of quantity and quality of yields have been studied and well documented. Many researchers reported that application of mineral fertilisers increases rice yield and the responses to fertilisers vary depending on varieties, soil-climate, and cultural practices (Min et al. 2007; Sukristiyonubowo 2007; Cho et al. 2002 and Cho et al. 2000; Fageria and Baligar 2001; Soepartini 1995; Uexkull 1989).

Many studies reported that the uptake of nutrients depends on variety, cultural practices, nutrients supply, and climate (Sukristiyonubowo and Du Laing 2011; Sukristiyonubowo and Tuherkih 2009; Yang et al. 2004; Sukristiyonubowo et al. 2003; Singh et al. 2001; Kemmler 1971; Sanchez and de Calderon 1971; Uexkull 1970). In accordance with variety and climate, Sukristiyonubowo (2007) and Uexkull (1970) observed that the total nutrients removals through rice grains and rice straw in the wet season ranged from 77 to $163 \mathrm{~kg} \mathrm{~N}, 14$ to $16 \mathrm{~kg}$ $\mathrm{P}$, and 150 to $198 \mathrm{~kg} \mathrm{~K} \mathrm{ha}^{-1}$ season $^{-1}$ and these were lower than in the dry season. According to Uexkull (1970), high yielding rice variety needed about 2.5 times more $\mathrm{N}$ and $\mathrm{P}$ and 4.5 times more $\mathrm{K}$ than the traditional varieties. Furthermore, Sukristiyonubowo (2007) and Uexkull (1970) reported that nutrient concentrations in high yielding varieties from 1.50 to $1.59 \% \mathrm{~N}, 0.19$ to $0.32 \% \mathrm{P}$ and 0.30 to $0.37 \% \mathrm{~K}$ were found in rice grains and from 1.05 to $1.28 \%$ $\mathrm{N}, 0.09$ to $0.14 \% \mathrm{P}$ and 1.78 to $2.47 \% \mathrm{~K}$ were observed in rice straw. Hence, nutrients removed through harvest products of high yielding varieties were higher than local varieties. Depending on nutrient inputs and climate, the total nutrients removed through harvest products of high yielding varieties ranged between 192 and $248 \mathrm{~kg} \mathrm{~N}, 24$ and $34 \mathrm{~kg} \mathrm{P}, 125$ and $198 \mathrm{~kg} \mathrm{~K} \mathrm{ha}^{-1} \mathrm{yr}^{-1}$ (Sukristiyonubowo and Du Liang 2010; Uexkull 1970). Yang et al. (2004) observed that incorporation of organic manure in alternating wet and dry water regimes significantly increased N, P, and $\mathrm{K}$ uptakes by the rice plants and facilitated translocation of $\mathrm{P}$ to rice panicles and grains. Significant improvements in nutrient uptake, rice grains and rice straw yields were also observed in trials combining $12.5 \mathrm{Mg} \mathrm{ha}^{-1}$ of Gliricidia leaves manure with inorganic phosphate fertilizer
(Kaleeswari and Subramanian 2004). Another study reported that applications of different sources of organic matter in the rice-wheat cropping system statistically increased total uptake of N, P, and K and rice yield (Singh et al. 2001). Therefore, it is interesting to study nutrient removal by harvest product and to properly manage its fertility status to sustain rice farming in newly opened wetland rice.

\section{MATERIALS AND METHODS}

\section{Study Sites and Design}

Field experiment was carried out in Ultisols soils of Panca Agung Village; Bulungan District, east Kalimantan Province (Figure 1) in 2009 from June to October 2009.

Six treatments were tested including T0: farmers practices (as control), T1: farmer practices + straw compost + dolomite, T2: NPK with recommendation rate, in which $\mathrm{N}$ and $\mathrm{K}$ were split two times, T3: NPK with recommendation rate, in which $\mathrm{N}$ and $\mathrm{K}$ was split three times, T4: NPK with recommendation rate in which $\mathrm{N}$ and $\mathrm{K}$ were split three times + straw compost + dolomite, and T5: NPK with recommendation rate in which $\mathrm{N}$ and $\mathrm{K}$ were split two times + straw compost + dolomite. They were arranged in Randomized Completely Block Design and replicated three times. The plot sizes were $5 \mathrm{~m} \times 5 \mathrm{~m}$ with the distance among plot was $50 \mathrm{~cm}$ and between replication was $100 \mathrm{~cm}$. NPK fertilizer used originated from single fertiliser namely urea, super phosphate-36 (SP-36) and potassium chloride $(\mathrm{KCl})$. Based on the direct measurement with Soil Test Kits for wetland rice (Perangkat Uji Tanah Sawah), the recommendation rate was determined about $250 \mathrm{~kg}$ urea, $100 \mathrm{~kg}$ SP36 and $100 \mathrm{~kg} \mathrm{KCl} \mathrm{ha}^{-1}$, while the farmer practices rate was $100 \mathrm{~kg}$ urea and $100 \mathrm{~kg}$ SP-36 ha- . Treatments $\mathrm{T} 2$ and $\mathrm{T} 5$, urea and $\mathrm{KCl}$ were applied two times, $50 \%$ at planting time and $50 \%$ at 21 days

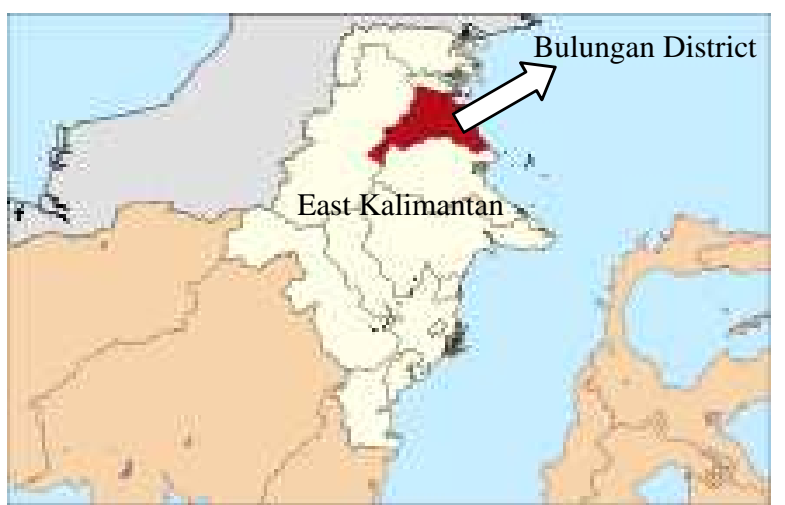

Figure 1. Map of location of experiment. 


\title{
Nutrient Removal by Rice Cultivated in Newly Opened Wetland Rice in Bulungan District, East Kalimantan
}

\author{
Sukristiyonubowo, Kusumo Nugroho and Tagus Vadari ${ }^{1}$ \\ ${ }^{1}$ Indonesian Soil Research Institute Jl. Tentara Pelajar No 12 Cimanggi, Bogor 16123, Indonesia, \\ e-mail: sukristiyonubowo@yahoo.com \\ Received 10 August 2011 / accepted 5 March 2012
}

\begin{abstract}
Highly weathered Indonesian soils and potential acid sulphate soils are mainly granted for developing newly opened wetland rice field to meet rice growing demand in Indonesia. Nutrient removal by rice harvest product of Ciliwung variety planted in newly opened wetland rice was studied in Bulungan District, in 2009. The aims were to examine the nutrient taken out by rice harvest product and to properly manage its fertility status to sustain rice farming. Six treatments were studied including T0: farmers practices, T1: farmer practices + compost + dolomite, T2: NPK recommended rate, N and K were split two times, T3: NPK recommended rate, N and K were split three times, T4: NPK recommended rate, N and K were split three times + compost + dolomite and T5: NPK recommended rate, $\mathrm{N}$ and $\mathrm{K}$ were split two times + compost + dolomite. The results indicated that the highest concentrations of $\mathrm{N}, \mathrm{P}$, and $\mathrm{K}$ in rice grain and rice straw were observed at NPK with recommendation rate in which $\mathrm{N}$ and $\mathrm{K}$ were split three times + straw compost + dolomite (T4). The T4 (NPK with recommendation rate in which N and K were split three times + straw compost + dolomite) also showed the highest nutrient removal by harvest product. Depending on the treatments, total nutrients removal through rice grains and rice straw varied from 61.81 to $101.71 \mathrm{~kg} \mathrm{~N}, 4.31$ to $13.69 \mathrm{~kg} \mathrm{P}$ and from 95.77 to $171.16 \mathrm{~kg} \mathrm{~K} \mathrm{ha}^{-1}$ season $^{-1}$, meaning that at least about 137 to $225 \mathrm{~kg}$ urea, 50 to 160 $\mathrm{kg} \mathrm{SP}-36$ and 190 to $339 \mathrm{~kg} \mathrm{KCl} \mathrm{ha}^{-1}$ season $^{-1}$ should be given to replace nutrient removed by harvest product and to avoid any nutrients depletion. When all rice straws were returned to the field as compost, about 55 to $133 \mathrm{~kg}$ urea, 25 to $110 \mathrm{~kg} \mathrm{SP}-36$ and 10 to $19 \mathrm{~kg} \mathrm{KCl} \mathrm{ha}^{-1}$ season $^{-1}$ should be added to substitute nutrient removed by rice grain.
\end{abstract}

Keywords: Newly opened wetland rice, nutrient removal, rice harvest product

\section{INTRODUCTION}

In Indonesia over two third of total population depend on agricultural sector and wetland rice plays an important role in sustaining food security and building rural livelihood like providing job and income. Therefore, rice is not only taking effect in social and economic aspects, but also political life in Indonesia. However, recently the Indonesian agricultural faces many problems including producing more rice with limited soil and water to meet rice growing demand. In addition, in rice farming, application of fertilizers rate and crop residue management differ among farmers within sub district, resulting variability in production and soil fertility properties. The shrinking of agricultural land and harvest areas in Indonesia due to: a) increasing agricultural land conversion to non-agricultural purposes, b) increasing water competition among agricultural sector and industrial as well as domestic

J Trop Soils, Vol. 17, No. 2, 2012:115-120 ISSN 0852-257X purposes, and c) water pollution reducing total harvest areas are also agriculture challenge ahead to sustain rice security (Baghat et al. 1996; Bouman and Tuong 2001; Sukristiyonubowo 2007; Sukristiyonubowo et al. 2011).

Highly weathered Indonesian soils as well as potential acid sulphate soils in outside Java and Bali Islands are mainly granted for developing newly opened wetland rice field to meet rice growing demand in Indonesia. The soils are acidic with low natural level of major plant nutrients, but having toxic levels of Al, Mn and Fe (Sudjadi 1984; Sukristiyonubowo et al. 2011). Theoretically, the soils fertility status can effectively be improved with addition of mineral fertilisers and balance fertilization of $\mathrm{N}, \mathrm{P}$ and $\mathrm{K}$ promote microbial biomass growth as well as improve community composition (Dobbermann et al. 1996; Zhang and Wang 2005). However, for the smallholder farmers including the farmers living in transmigration areas, the costs to purchase the fertilisers are problem. The chemical fertilizer in enough quantity is beyond their financial reach. Consequently, to sustain crop 